\title{
Juvenile Dermatomyositis in Turkish Children
}

\author{
Türk Çocuklarında Juvenil Dermatomiyozit \\ Sebahat TÜLPAR, M. Hakan POYRAZOĞLU, Zübeyde GÜNDÜZ, Ruhan DÜŞÜNSEL, Funda BAŞTUĞ \\ Department of Pediatric Nephrology, Medical Faculty of Erciyes University, Kayseri, Turkey
}

Objectives: This study aims to determine the clinical features of juvenile dermatomyositis (JDM) in Turkish children.

Patients and methods: The clinical records of nine children with JDM who were followed up in the Department of Pediatric Nephrology and Rheumatology of Erciyes University Faculty of Medicine between January 1992 and December 2008 were reviewed retrospectively.

Results: The female to male ratio was 2:1. The median age at onset of the disease was 8.8 years (range 6.5-14 years), the median duration of symptoms before diagnosis was two months (range 10 days-72 months), and the mean time of follow-up was 49.5 months (range 2-96 months). The main presenting complaints were arthritis/arthralgia, myalgia, an impaired ability to walk, and skin rashes. Eight patients received oral steroids as the initial therapy. Additionally, two patients received intravenous methylprednisolone, and five received non-steroidal antiinflammatory drugs during the follow-up. Three patients received methotrexate, and one received cyclosporine $A$. The median time to treatment response was 60 days (range 10-70 days). Pathological proteinuria was found in two patients. Subcutaneous calcinosis developed in one patient. Skin and soft-tissue infections occurred in two patients. Other complications seen during the follow-up were malnutrition, obesity, depressive mood, ototoxicity, muscle weakness, osteoporosis, and contractures.

Conclusion: Although juvenile dermatomyositis is a rare disease in childhood, it may have severe complications.

Key words: Immunosuppressive agents; juvenile dermatomyositis; retrospective study.
Amaç: Bu çalışma Türk çocuklarda juvenil dermatomiyozitin (JDM) klinik özelliklerini tanımlamayı amaçlamaktadır.

Hastalar ve yöntemler: Ocak 1992 - Aralık 2008 tarihleri arasında Erciyes Üniversitesi Tıp Fakültesi Çocuk Nefroloji ve Romatoloji Departmanı'nda takip edilmiş olan dokuz JDM'li çocuğun tıbbi kayıtları retrospektif olarak incelendi.

Bulgular: Kız erkek oranı 2:1 idi. Hastalığın başlangıç yaş ortancası 8.8 yıl (dağılım 6.5-14 yıl), tanı öncesi semptomların ortanca süresiiki ay (dağılım 10 gün-72ay), ortalama takip süresi ise 49.5 ay (dağılım 2-96 ay) idi. Başlıca başvuru yakınmaları artrit/artralji, miyalji, yürüme yeteneğinde bozukluk ve ciltte döküntü idi. Başlangıç tedavisi olarak sekiz hastaya oral steroid verildi. Takipleri sırasında ek olarak, iki hastaya intravenöz metilprednizolon, beş hastaya nonsteroid antiinflamatuvar ilaçlar verildi. Üç hastaya metotreksat ve bir hastaya siklosporin A verildi. Tedaviye yanıt gelişene kadar geçen ortanca süre 60 gün (dağılım 10-70 gün) idi. İki hastada patolojik proteinüri tespit edildi. Bir hastada cilt altında kalsinozis oluştu. İki hastada cilt ve yumuşak doku infeksiyonu gelişti. Beslenme bozukluğu, şişmanlık, depresif duygu durumu, ototoksisite, kas güçsüzlüğü, osteoporoz ve kontraktürler hastaların takipleri sırasında görülen diğer komplikasyonlardı.

Sonuç: Juvenil dermatomiyozit çocukluk çağında nadir görülen bir hastalık olmaşna rağmen ciddi komplikasyonları olabilir.

Anahtar sözcükler: Immünosüpresif ajanlar; juvenil dermatomiyozit; retrospektif çalışma. 
Juvenile dermatomyositis (JDM) is a vasculopathy of the skin and muscle and is the most common idiopathic inflammatory myositis in children with an estimated annual incidence of 2-3 per million children. In addition to the involvement of skin and skeletal muscles, JDM can affect other organs which may cause severe or life-threatening complications. Rash and muscle weakness of specific distribution are the most important diagnostic clues. ${ }^{[1-3]}$ Early diagnosis and aggressive treatment can lead to remission and prevention of severe complications. ${ }^{[1,4,5]}$ This is the first study reviewed which takes into account all clinical, laboratory, and pathological features of Turkish children with JDM treated at our center over the last 16 years.

\section{PATIENTS AND METHODS}

We retrospectively evaluated the medical records of nine children ( 6 girls, 3 boys mean age 8.8 years; range 6.5 to 14 years) with JDM who were treated in the Department of Pediatric Nephrology and Rheumatology, Erciyes University Medical Faculty between January 1992 and December 2008. Diagnoses were based on Bohan and Peter's criteria. ${ }^{[6]}$ The onset of the diagnosis of JDM occurred at or before 16 years of age. For each patient, the following data were analyzed: gender, age, presenting symptoms and clinical features, time to diagnosis (duration between onset of symptoms and diagnosis), laboratory values at time of diagnosis, electromyography and muscle biopsy results, disease course, duration of follow-up, treatment, outcome, and complications. Laboratory parameters included white blood cell (WBC) counts, hemoglobin, erythrocyte sedimentation rate (ESR), lactate dehydrogenase (LDH), aspartate aminotransferase (AST), alanine aminotransferase (ALT), creatinine kinase (CK), antinuclear antibody (ANA), and urinalysis.

\begin{tabular}{lc}
\hline $\begin{array}{l}\text { Table 1. The most common findings of juvenile } \\
\text { dermatomyositis at presentation }\end{array}$ & \\
\hline Findings & Number \\
\hline Cutaneous changes & 9 \\
Arthritis/arthralgia & 7 \\
Myalgia & 7 \\
Proximal muscle weakness & 6 \\
Gottron's papules & 4 \\
Heliotroph rash & 4 \\
Edema & 3 \\
Fatigue & 2 \\
Fever & 1 \\
\hline
\end{tabular}

\section{RESULTS}

The onset of symptoms occurred during the winter $(n=5)$, autumn $(n=2)$, and summer $(n=1)$. We could not determine the season when symptoms appeared in one patient. The median duration of symptoms before diagnosis was two months (range 10 days-72 months). The mean time of follow-up was 49.5 months (range, 2-96 months). The most common findings at presentation are summarized in table 1 . At the time of admission, mean \pm standard deviation $( \pm$ SD) WBC counts were $7700 \pm 2700 / \mathrm{mm}^{3}$ (range 4600 $\left.12700 / \mathrm{mm}^{3}\right)$. The mean $( \pm \mathrm{SD})$ level of hemoglobin was $12.6 \pm 1.2 \mathrm{~g} / \mathrm{dl}$ (range 10.9-14.4). Five patients had an elevated ESR with a range of $53-200 \mathrm{~mm} / \mathrm{h}$. The median (min-max) level of LDH, AST, ALT and CK was 686 IU/l (range 146-3759 IU/l), 274 IU/1 (range 57-1555 IU/l), 207 IU/l (range 34-564 IU/l), and $2938 \mathrm{IU} / \mathrm{l}$ (range 94-16408 IU/l), respectively. Antinuclear antibodies were seen in only one of the six patients tested. Electromyography was performed on eight patients which revealed typical myopathic type changes in all patients. A muscle biopsy was performed on four patients and was compatible with myositis (table 2).

All patients received oral steroids as the initial therapy, except for one patient whose illness was chronic at the time of diagnosis. Additionally, two patients received intravenous (iv) methylprednisolone, and five received nonsteroidal anti-inflammatory drugs. Three patients were given methotrexate, and one was given cyclosporin $\mathrm{A}$. The median time of response to treatment was 60 days (range 10-70 days; table 3).

Vasculitis of the eye was determined in one patient (figures 1 and 2). Pathological proteinuria

\begin{tabular}{lc}
$\begin{array}{l}\text { Table 2. Abnormalities of laboratory } \\
\text { presentation }\end{array}$ & findings at \\
\hline Laboratory studies & Abnormal/tested \\
\cline { 2 - 2 } & (Number) \\
\hline White blood cell & $1 / 9$ \\
Hemoglobin & $3 / 9$ \\
Erythrocyte sedimentation rate & $5 / 9$ \\
Lactate dehydrogenase & $5 / 7$ \\
Aspartate aminotransferase & $8 / 8$ \\
Alanine aminotransferase & $7 / 8$ \\
Creatinine kinase & $7 / 8$ \\
Antinuclear antibody & $1 / 5$ \\
Electromyography & $8 / 8$ \\
Muscle biopsy & $4 / 4$
\end{tabular}


Table 3. Clinical characteristics of patients with juvenile dermatomyositis

\begin{tabular}{|c|c|c|c|c|c|c|c|}
\hline Patient & $\begin{array}{c}\text { Age at } \\
\text { onset/sex } \\
\text { (year) }\end{array}$ & $\begin{array}{c}\text { Duration } \\
\text { (onset-diagnosis), } \\
\text { (months) }\end{array}$ & $\begin{array}{l}\text { Complaints upon } \\
\text { admission }\end{array}$ & Treatment & $\begin{array}{l}\text { Time } \\
\text { responded to } \\
\text { treatment, } \\
\text { (months) }\end{array}$ & $\begin{array}{l}\text { Follow-up } \\
\text { (months) }\end{array}$ & Complications \\
\hline 1 & $6.5 / F$ & 2 & $\begin{array}{l}\text { Skin rashes, myalgia, } \\
\text { arthralgia, abdominal } \\
\text { pain, impaired ability } \\
\text { to walk }\end{array}$ & Oral corticosteroid & 2 & 35 & - \\
\hline 2 & $9.4 / \mathrm{F}$ & 1.5 & $\begin{array}{l}\text { Fatigue, weakness, } \\
\text { anorexia, arthritis, } \\
\text { skin rashes }\end{array}$ & Oral corticosteroid & 2 & 96 & - \\
\hline 3 & $7.8 / \mathrm{F}$ & 0.8 & $\begin{array}{l}\text { Arthralgia/arthritis, } \\
\text { impaired ability to walk, } \\
\text { swelling, skin rashes }\end{array}$ & $\begin{array}{l}\text { Oral corticosteroid, } \\
\text { NSAID, cyclosporine } \\
\text { A, Methotrexate }\end{array}$ & 1 & 58 & $\begin{array}{l}\text { Proteinuria, tachicardia, } \\
\text { osteoporosis, hypertension, } \\
\text { pyoderma, obesity, } \\
\text { hyperlipidemia, short stature, } \\
\text { depression, dysphagia }\end{array}$ \\
\hline 4 & $12 / \mathrm{F}$ & 0.3 & $\begin{array}{l}\text { Arthralgia, myalgia, } \\
\text { skin rashes }\end{array}$ & Oral corticosteroid & 0.3 & 72 & - \\
\hline 5 & $8.8 / \mathrm{F}$ & 3 & $\begin{array}{l}\text { Arthralgia, impaired } \\
\text { ability in writing, loss in } \\
\text { weight, difficulty raising } \\
\text { the legs }\end{array}$ & $\begin{array}{l}\text { Oral corticosteroid, } \\
\text { NSAID }\end{array}$ & 2 & 46 & Proteinuria \\
\hline 6 & $14 / \mathrm{M}$ & 2 & $\begin{array}{l}\text { Diffuse pain, impaired } \\
\text { ability to walk, difficulty } \\
\text { raising the legs }\end{array}$ & $\begin{array}{l}\text { Oral corticosteroid, } \\
\text { PMP, NSAID, } \\
\text { methotrexate }\end{array}$ & 2.3 & 39 & $\begin{array}{l}\text { Malnutrition, cellulitis, } \\
\text { muscle atrophy, muscle } \\
\text { weakness, calcinosis, } \\
\text { ototoxicity, hypopigmentation }\end{array}$ \\
\hline 7 & $11 / \mathrm{F}$ & 72 & Myalgia, swelling & $\begin{array}{l}\text { Oral corticosteroid, } \\
\text { PMP }\end{array}$ & 1.5 & 2 & Dysphagia \\
\hline $8^{*}$ & $8.8 / \mathrm{M}$ & 60 & $\begin{array}{l}\text { Impaired ability to walk, } \\
\text { growth retardation }\end{array}$ & NSAID & & 96 & $\begin{array}{l}\text { Contracture, short stature, } \\
\text { malnutrition, } \\
\text { hypopigmentation }\end{array}$ \\
\hline 9 & $6.5 / \mathrm{M}$ & 2 & $\begin{array}{l}\text { Fatigue, impaired ability } \\
\text { to walk, arthralgia, fever }\end{array}$ & $\begin{array}{l}\text { Oral corticosteroid, } \\
\text { NSAID, methotrexate }\end{array}$ & 2 & 2 & Onychomycosis \\
\hline
\end{tabular}

was determined in two patients. A renal biopsy was performed on one child. The renal biopsy specimens were studied by light microscopy and immunofluorescence, and the findings of the biopsy were normal. Subcutaneous calcinosis developed in one patient. Skin and soft-tissue infections occurred in two patients. Other complications seen on followup were malnutrition, obesity, depression, ototoxicity, muscle weakness, osteoporosis, and contracture (table 3).

At the latest follow-up, four of nine patients were in remission without immunosuppressive agents, three patients were in remission with immunosuppressive agents, and two patients were in remission with sequela. Six patients were lost to follow-up but three continue to be followed up.
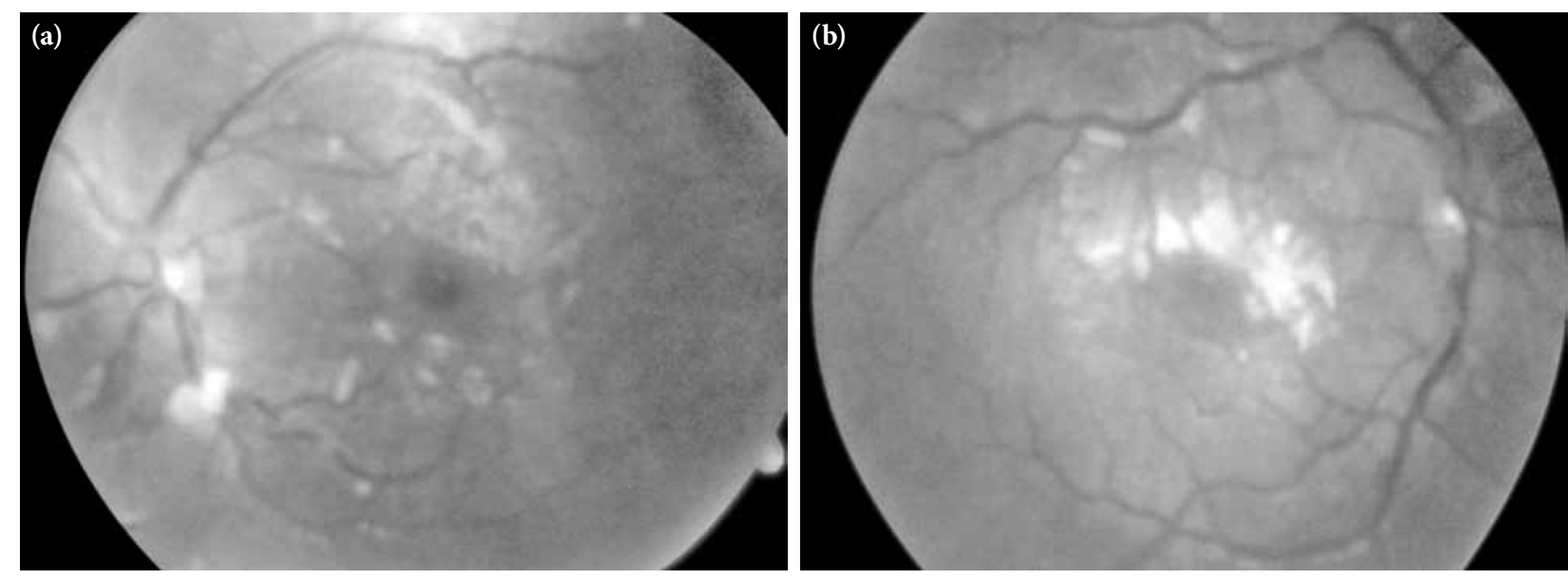

Figure 1. Fundoscopy showed a microangiopathy in the (a) left and (b) right eye at admission to our department. 

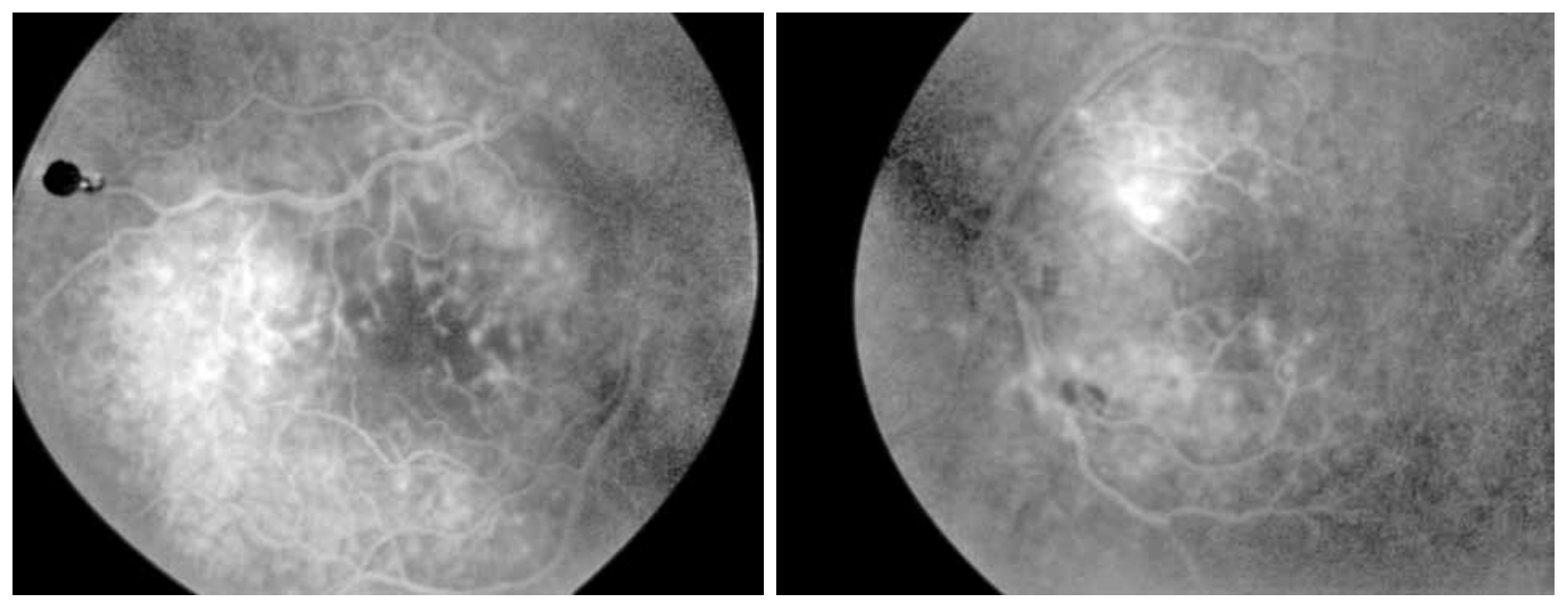

Figure 2. Vasculitis was demonstrated in the bilateral eye on fundus fluorescein angiography.

\section{DISCUSSION}

This retrospective analysis describes the clinical spectrum of JDM in the pediatric population from a single tertiary center.

In our study, the occurrence of symptoms in our patients was more frequent in the winter season. There are some publications which have described the onset of JDM occurring more frequently in the winter and spring. ${ }^{[7,8]}$ In our study, the beginning of symptoms was not present in the spring.

Although the etiology of JDM is unknown, it is considered that infectious agents play a role as triggering factors. ${ }^{[1-3]}$ Prior to the occurrence of JDM, our three patients had a history of having upper respiratory tract infections. Rider and Miller ${ }^{[9]}$ reported that hepatitis $\mathrm{B}$, measles, mumps, and rubella (MMR), typhoid, and cholera vaccinations were triggering factors in juvenile idiopathic inflammatory myopathies. One of our patients had a history of measles vaccination prior to the onset of symptoms.

Only four patients complained of rash, even though all patients were found to have skin rashes upon examination. If a careful physical examination is not performed, the rash may be overlooked.

We found that one of our patients had retinal vasculitis. Retinopathy is very rarely observed in dermatomyositis (DM) and JDM. ${ }^{[10]}$ There are a few case reports about retinopathy in JDM. ${ }^{[11-13]}$ Furthermore, Akikusa et al. ${ }^{[14]}$ recently retrospectively studied the eye involvement in 82 patients with JDM. Two of these patients were found to have retinopathy. In a case report regarding a 14 -year-old patient with JDM reported by Wienfield, retinopathy presented with transient visual loss. ${ }^{[1]}$ In our case, the patient had no sign of retinopathy. It has also been reported that retinopathy leads to irreversible visual loss. ${ }^{[15]}$ Although retinopathy is rarely observed in patients with JDM, periodic eye examinations should be performed since retinopathy may lead to the persistent loss of vision which would affect the quality of life.

We found proteinuria in two patients. Proteinuria had a transient nature in one patient whereas it was persistent in the other patient. Renal involvement is rarely observed in JDM and DM. Renal pathologies, such as membranous nephropathy, IgA nephropathy, and ATN, were reported. ${ }^{[16-18]}$ We consider that the performance of urine examinations in the follow-up of the patients is important so as not to overlook renal involvement.

We observed hypertension and sinus tachycardia in one patient who had been diagnosed on an echocardiogram as having a deformation of the mitral front fibers. Cardiac involvement is rare in JDM. In a study, three patients had tachycardia among 35 patients with JMD. ${ }^{[19]}$ Heart murmurs, pericarditis, and electrocardiogram (ECG) abnormalities are also seen in JDM..$^{[10]}$

We observed dysphagia in our two patients. Esophageal symptoms occur in $6-41 \%$ of patients with JDM. ${ }^{[20]}$ The involvement of the pharynx muscles and upper esophagus may lead to dysphagia. Owing to an increased aspiration risk, nutrition with a nasogastric tube is recommended until the improvement of dysphagia. ${ }^{[21,22]}$

Skin-subcutaneous infection developed in our two patients. When the infection developed, JDM in both 
patients was active, and they were using steroids. Onychomycosis was observed in one patient who received steroids and methotrexate therapy at the time onychomycosis occurred. We considered that the tendency toward infection may have increased due to JDM itself and/or immunosuppressive agents.

Calcinosis is a late finding of JDM and is observed one to three years after disease onset. ${ }^{[2,3]}$ We observed calcinosis in one patient. As for this patient, JDM had run a chronical course and calcinosis developed six months after the presence of cellulitis in his extremities. Infection may have had a triggering effect on the calcinosis development.

Two patients developed hypopigmentation. During the follow-up of these patients, muscle weakness did not improve completely, atrophy developed, and knee movements were restricted. These two patients had persistent muscle inflammation, and it is very likely that their skin disease was also active, causing the hypopigmentation.

Depression developed in one patient, and we considered it an adverse effect associated with corticosteroids and cyclosporine. Central nervous system involvement in JDM may be observed as central nervous system vasculitis, hypoxic ischemic encephalopathy, hypertensive encephalopathy, and drug-related toxicity. ${ }^{[2]}$

Furthermore, we observed obesity, short stature, autotoxicity, and osteoporosis as treatment complications in our patients.

Sequela in JDM usually occurs due to calcinosis and flexion contracture. ${ }^{[3,20,22]}$ In our study, both of the patients with sequela had flexion contracture, and one of them had calcinosis as well.

Finally, based on our results, although JDM is a rare disease in childhood, it may have severe complications. All children with JDM should be followed up closely. This study had limitations because it was conducted at a single center, and the patient number was relatively small. Multicenter studies are needed to fully define the clinical spectrum and outcome of JDM in Turkish children.

\section{Declaration of conflicting interests}

The authors declared no conflicts of interest with respect to the authorship and/or publication of this article.

\section{Funding}

The authors received no financial support for the research and/or authorship of this article.

\section{REFERENCES}

1. Woo P, Laxer RM, Sherry DD. Juvenile dermatomyositis. In: Woo P, Laxer RM, Sherry DD, editors. Pediatric Rheumatology in clinical practice. 1st ed. London: Springer; 2007. p. 66-76.

2. Compeyrot-Lacassagne S, Feldman BM. Inflammatory myopathies in children. Pediatr Clin North Am 2005;52:493-520.

3. Feldman BM, Rider LG, Reed AM, Pachman LM. Juvenile dermatomyositis and other idiopathic inflammatory myopathies of childhood. Lancet 2008;371:2201-12.

4. Fisler RE, Liang MG, Fuhlbrigge RC, Yalcindag A, Sundel RP. Aggressive management of juvenile dermatomyositis results in improved outcome and decreased incidence of calcinosis. J Am Acad Dermatol 2002;47:505-11.

5. Kim S, El-Hallak M, Dedeoglu F, Zurakowski D, Fuhlbrigge RC, Sundel RP. Complete and sustained remission of juvenile dermatomyositis resulting from aggressive treatment. Arthritis Rheum 2009;60:1825-30.

6. Bohan A, Peter JB. Polymyositis and dermatomyositis (first of two parts). N Engl J Med 1975;292:344-7.

7. McCann LJ, Juggins AD, Maillard SM, Wedderburn LR, Davidson JE, Murray KJ, et al. The Juvenile Dermatomyositis National Registry and Repository (UK and Ireland)-clinical characteristics of children recruited within the first $5 \mathrm{yr}$. Rheumatology (Oxford) 2006;45:1255-60.

8. Pachman LM, Hayford JR, Hochberg MC. Seasonal onset in juvenile dermatomyositis: an epidemiological study. Arthritis Rheum 1992;35:S88.

9. Rider LG, Miller FW. Classification and treatment of the juvenile idiopathic inflammatory myopathies. Rheum Dis Clin North Am 1997;23:619-55.

10. Dourmishev LA, Dourmishev AL. Pharmacologic agents in the treatment of DM. In: Dourmishev LA, Dourmishev $\mathrm{AL}$, editors. Dermatomyositis advances in recognition, understanding and management. 1st ed. Berlin: Springer; 2009. p. 297-322.

11. Winfield J. Juvenile dermatomyositis with complications. Proc R Soc Med 1977;70:548-51.

12. Cohen BH, Sedwick LA, Burde RM. Retinopathy of dermatomyositis. J Clin Neuroophthalmol 1985;5:177-9.

13. Lenoble P, Desprez P, Fischbach M, Flament J, Sahel J. Ocular involvement in dermatomyositis. Apropos of the case of a 15-year-old girl. J Fr Ophtalmol 1995;18:312-6. [Abstract]

14. Akikusa JD, Tennankore DK, Levin AV, Feldman BM. Eye findings in patients with juvenile dermatomyositis. J Rheumatol 2005;32:1986-91.

15. Yeo LM, Swaby DS, Situnayake RD, Murray PI. Irreversible visual loss in dermatomyositis. Br J Rheumatol 1995;34:1179-81.

16. Soylu A, Kavukçu S, Türkmen M, Saroğlu S. Dermatomyositis with membranous nephropathy. Turk J Pediatr 2001;43:143-5. 
17. Yen TH, Huang JY, Chen CY. Unexpected IgA nephropathy during the treatment of a young woman with idiopathic dermatomyositis: case report and review of the literature. J Nephrol 2003;16:148-53.

18. Yen TH, Lai PC, Chen CC, Hsueh S, Huang JY. Renal involvement in patients with polymyositis and dermatomyositis. Int J Clin Pract 2005;59:188-93.

19. Sallum AM, Kiss MH, Sachetti S, Resende MB, Moutinho KC, Carvalho Mde S, et al. Juvenile dermatomyositis: clinical, laboratorial, histological, therapeutical and evolutive parameters of 35 patients. Arq Neuropsiquiatr 2002;60:889-99.
20. DourmishevLA,DourmishevAL.JuvenileDermatomyositis. In: Dourmishev LA, Dourmishev AL, editors. Dermatomyositis advances in recognition, understanding and management. 1st ed. Berlin: Springer; 2009. p. 135-46.

21. Dourmishev LA, Dourmishev AL. Gastrointestinal complications of dermatomyositis. In: Dourmishev LA, Dourmishev AL, editors. Dermatomyositis advances in recognition, understanding and management. 1st ed. Berlin: Springer; 2009. p. 89-92.

22. Pilkington C. Juvenile dermatomyositis. In: Cimaz R, Lehman T, editors. Pediatrics in systemic autoimmune diseases, 1st ed. Amsterdam: Elsevier; 2008. p. 89-98. 